\title{
Hydro-meteorological characteristics of Chitral River basin at the peak of the Hindukush range
}

\author{
Salma Khalid ${ }^{1 *}$, Shafiq Ur Rehman ${ }^{2}$, Syed Mushtaq Ali Shah ${ }^{3}$, Alia Naz $^{1}$, Beena Saeed ${ }^{4}$, \\ Sadia Alam ${ }^{5}$, Farman Ali $^{4}$, Hasina Gul ${ }^{6}$ \\ ${ }^{1}$ Department of Environmental Sciences, Abdul Wali Khan University, Mardan, Pakistan; \\ *Corresponding Author: anagalious 79@yahoo.com \\ ${ }^{2}$ Department of Environmental Sciences, University of Peshawar, Peshawar, Pakistan \\ ${ }^{3}$ Regional Meteorological Centre, Peshawar, Pakistan \\ ${ }^{4}$ Department of Agriculture, Abdul Wali Khan University, Mardan, Pakistan \\ ${ }^{5}$ Department of Biotechnology, Abdul Wali Khan University, Mardan, Pakistan \\ ${ }^{6}$ Department of Agronomy, University of Agriculture, Peshawar, Pakistan \\ Received 29 March 2013; revised 29 April 2013; accepted 7 May 2013 \\ Copyright (C) 2013 Salma Khalid et al. This is an open access article distributed under the Creative Commons Attribution License, \\ which permits unrestricted use, distribution, and reproduction in any medium, provided the original work is properly cited.
}

\section{ABSTRACT}

This paper presents the impact of mean maximum temperature on Chitral river basin situated at Chitral district and high altitude $(>6000 \mathrm{~m})$ peaks of the Hindukush range under changing climate in Pakistan. The analysis of Chitral River as one of the tributary of Kabul River-the second largest river of Pakistan-revealed that change in temperature has a profound influence on the snow/glacial melt in comparison to the mean monthly rainfall. This is because the studied river is faded by the snow and glacial melt and receives a lot of snowfall from winter (DecFeb) to pre-monsoon (April-May). In monsoon period (Jul-Sep), $30 \%$ of the time the discharge rate remains above the mean while $60 \%$ of the time the discharge is less than the mean in the pre-monsoon (April-May) period. It means that $10 \%$ of the time the discharge is in reach of $300 \%$ to $900 \%$ of the mean flow, showing a rise in water yield and river discharge rate due to increase in mean monthly maximum temperature. Due to this significant increase $(p<0.05)$, the glaciers start melting faster and disappear in early summer, hence, reducing their residency period to convert into ice. This shows the signals of changing climate transfer into hydrological changes in Pakistan. Our findings are important for agriculture, hydropower and water management sectors for future planning especially in dry season for sustainable food security and for operation of hydrological installations in the country.

Keywords: Mean Maximum Temperature; Mean Rainfall; River Discharge; Climate Change; Chitral

\section{INTRODUCTION}

The rising trend in temperatures, associated with the changes in precipitation pattern, enhances the hydrological cycle in the form of stream flow volume as well as its distribution throughout the year and temporally causing significant water stress [1]. According to Kundzewicz et al. [2] that discharge in glacier fed rivers will remain increase in the short term but decrease over the next few decades as slowly and gradually ice storage will diminished. It means that temperature change is one of the major factors, affecting precipitation distribution, which may be in the form of snow, glacier melting and rainfall and is considered as major contributor to the fresh water sources [3-6]. During the past two decades numerous studies have been conducted on the hydrological effects of climate change such as Ayers et al. [7], Gleick [8-10], Lettenmaier and Gan [11], Mather and Feddema [12], McCabe and Ayers [13], Nemec and Schaake [14], and Schaake [15] from different regions of the world. These studies mainly focus on the effects of changes in temperature and precipitation on mean monthly, seasonal, or annual river flows. In Pakistan, Rehman et al. [16] have reviewed discharge characteristics and suspended load of the northern Indus basins and concluded that most of the area show highest discharge during the July and the summer, and total ratio for most of the northern rivers is $>80 \%$. Pakistan is located in South Asia between $24^{\circ} 37^{\prime} \mathrm{N}$ 
latitude and $66^{\circ} 77^{\prime} \mathrm{E}$ and occupies a total geographical area of $803,943 \mathrm{~km}^{2}$ [17]. The country has Arabian Sea in the south bordering India in the east and Iran in the south east, Afghanistan on the north-west and China in the north. High mountains ranges comprise Himalaya and Karakoram ranges with a small part of the Hindukush range are present in the north of the country. Pakistan is the only place where these three great mountain ranges meet. There are more than 5000 glaciers contributing to the Indus River from 10 sub-basins through different tributaries [18]. The effects of global warming in mountain areas are visibly manifested by shrinking of mountain glaciers and reduced snow cover duration [19]. Glacier and Snowmelt water from these glaciers contributes significantly to the river flows in Pakistan [20]. It has one of the largest river network which mainly consists of river Indus, river Jhelum, river Chenab, river Kabul, river Ravi and river Sutlej. Several tributaries of the two big rivers i.e. Indus and Kabul originate from areas included in extreme north of Pakistan. These two rivers are fed by the snow and glacial melt as receiving a lot of snowfall in winter and the pre-monsoon dry season (April-May). The freshwater supply derived from snow and ice melt serves as a critical resource for irrigation and hydropower generation. Hydroelectric power remains the most economically viable and environmentally safest method to overcome the energy crises in the country. In addition, demand for agricultural and domestic water in particular increases significantly at hotter and drier times of the year as agriculture has always been the dominant user of surface water for irrigation. Meanwhile, due to industrial growth in the country, water demand for the industry is also on rise and might compete with agriculture and domestic water consumption. This paper is intended to discuss and review the hydro-meteorological characteristics and discharge rate on seasonal and monthly basis as well as to ascertain the effect of maximum temperature on Chitral River discharge. This type of information is useful not only for watershed management but also for irrigation, hydel power generation and disaster management sectors.

\section{STUDY AREA DESCRIPTION}

Chitral River is one of the major indirect tributaries of the Indus River arises near the Baroghil pass in Hindukush Mountains from Kunhar River as one of the tributary of Kabul river in Afghanistan (Figure 1). The upper most section of the Chitral River is known as Yarkhum River, between Mastuj and Chitral towns and downstream it is called Chitral River located between $35^{\circ} 50$ and $71^{\circ} 48$. The drainage area of Chitral River in Chitral is $11,396 \mathrm{~km}^{2}$. The mean annual runoff of the river for 34 years of record (1964-98) is $8670 \mathrm{Mm}^{3}$. The maximum recorded discharge was $1586 \mathrm{~m}^{3} / \mathrm{s}$ on $16^{\text {th }}$ July, 1973 and

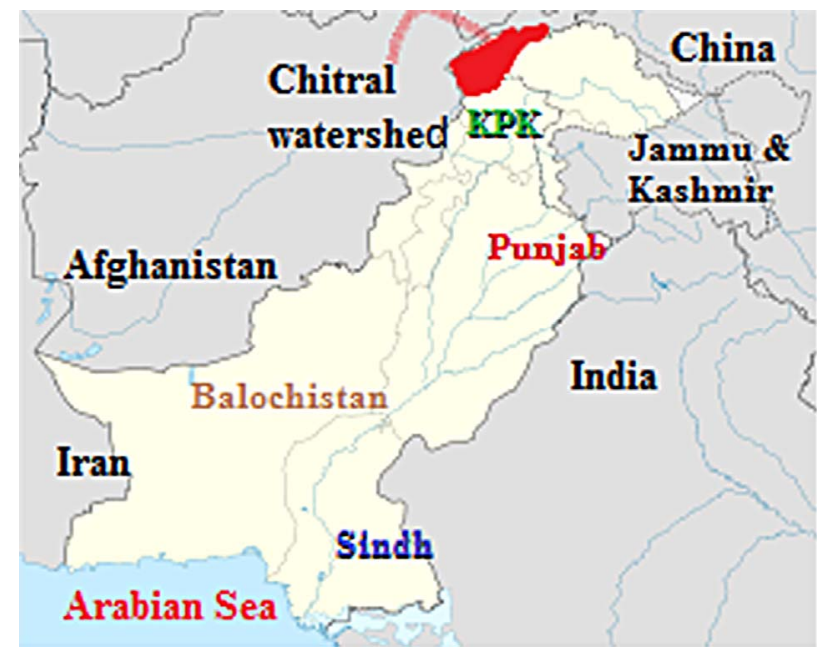

Figure 1. Map of Pakistan showing Chitral watershed.

the minimum recorded discharge was $46 \mathrm{~m}^{3} / \mathrm{s}$ on $10^{\text {th }}$ March, 1964. The river is glacier/ snow fed and it flows steadily throughout the year with additional runoff during the monsoon period i.e. Jul-Sept [20]. It drains an extensive area of high relief and snow cover in Chitral and subsequently contributes well over half of the discharge of the Kabul River. About $30 \mathrm{~km}$ west of Peshawar, the Kabul River was dammed for irrigation and hydel power generation with and optimum capacity of $250,000 \mathrm{~kW}$. However, due to extensive silting during the last thirty years, the reservoir is almost full and power generation has dropped to a range of $20,000-64,000 \mathrm{~kW}$ during winters and summers, respectively $[16,21]$.

\section{DATA AND METHOD}

The dataset used in this study consisted of mean minimum and maximum temperatures and rainfall records obtained from the Climate Data Processing Centre (CDPC) of Pakistan Meteorological Department (PMD) while river discharge data was acquired from Water and Power Supply Development Authority (WAPDA). In order to analyze the data and determine trends in temperature, rainfall changes and their effects on the Chitral River flow, means were computed for the 5 years and entire period (1976-2000). The reliability of data and homogeneity of means were statistically tested by applying different statistical tests, using SPSS version 20.

\section{RESULTS AND DISCUSSION}

Interpretation of each variable i.e. mean minimum and maximum temperatures, mean rainfall and mean river flow was performed separately into 5 years for trend significance (Table 1) and 25 years analysis for the influence determination of temperature on river discharge rate through hydro-meteorological characteristics of river basin analysis for the entire study period i.e. 1976-2000 (Table 2). 
Table 1. Five years trend of hydro-meteorological variables.

\begin{tabular}{|c|c|c|c|c|c|}
\hline \multirow[t]{2}{*}{ Hydro-Meteorological variables } & \multirow[t]{2}{*}{ Years } & \multirow[t]{2}{*}{ Mean } & \multirow[t]{2}{*}{ Std. Error } & \multicolumn{2}{|c|}{ 95\% CI for Mean } \\
\hline & & & & Upper Value & Lower Value \\
\hline \multirow{3}{*}{ Mean Minimum temperature } & 1976-1980 & 9.0 & 0.1 & 8.6 & 9.4 \\
\hline & 1981-1985 & 8.9 & 0.1 & 8.6 & 9.2 \\
\hline & 1986-1990 & 8.4 & 0.2 & 7.9 & 8.9 \\
\hline \multirow{2}{*}{$\mathrm{F}=0.96, \mathrm{p}=0.45$} & 1991-1995 & 9.0 & 0.4 & 8.0 & 9.9 \\
\hline & $1996-2000$ & 8.8 & 0.3 & 8.0 & 9.6 \\
\hline \multirow{5}{*}{ Mean Maximum temperature } & 1976-1980 & 23.6 & 0.4 & 22.6 & 24.6 \\
\hline & 1981-1985 & 23.1 & 0.3 & 22.2 & 24.0 \\
\hline & $1986-1990$ & 23.7 & 0.1 & 23.4 & 24.0 \\
\hline & 1991-1995 & 23.0 & 0.3 & 21.9 & 23.7 \\
\hline & $1996-2000$ & *24.2 & 0.3 & 23.3 & 25.0 \\
\hline \multirow{5}{*}{$\begin{array}{c}\text { Mean Rainfall } \\
\mathrm{F}=10.53, \mathrm{p}=0.00^{*}\end{array}$} & 1976-1980 & 26.9 & 3.1 & 18.2 & 35.6 \\
\hline & 1981-1985 & 32.8 & 3.7 & 22.6 & 43.0 \\
\hline & 1986-1990 & 44.3 & 3.7 & 34.0 & 54.7 \\
\hline & 1991-1995 & ${ }^{*} 53.1$ & 3.3 & 43.9 & 62.3 \\
\hline & $1996-2000$ & 42.6 & 1.2 & 39.3 & 45.9 \\
\hline \multirow[t]{2}{*}{ Mean River discharge } & 1976-1980 & 262.0 & 6.8 & 243.3 & 280.7 \\
\hline & 1981-1985 & 267.6 & 15.1 & 225.7 & 309.5 \\
\hline \multirow[t]{3}{*}{$\mathrm{F}=7.134, \mathrm{p}=0.00^{*}$} & $1986-1990$ & 272.8 & 17.2 & 225.1 & 320.5 \\
\hline & 1991-1995 & *295.4 & 10.3 & 266.8 & 324.0 \\
\hline & $1996-2000$ & ${ }^{*} 285.2$ & 6.0 & 268.4 & 302.0 \\
\hline
\end{tabular}

${ }^{*}$ Most significant $\mathrm{p}<0.05$.

Table 2. Hydro-meteorological characteristics of Chitral River basin on mean monthly basis.

\begin{tabular}{ccccc}
\hline \multicolumn{5}{c}{ Chitral River $\mathbf{( 7 6 6 , 6 2 2} \mathbf{~ m}^{\mathbf{3}} / \mathbf{s}$ water yield per annum) } \\
\hline Months & Min Temp $\left({ }^{\circ} \mathbf{C}\right)$ & Max Temp $\left({ }^{\circ} \mathbf{C}\right)$ & Rainfall $(\mathbf{m m})$ & Discharge $\left(\mathbf{m}^{\mathbf{3}} / \mathbf{s}\right)$ \\
\hline Jan & -0.51 & 9.45 & 47.82 & 77.15 \\
Feb & 0.80 & 10.68 & 57.19 & 68.36 \\
Mar & 3.91 & 14.83 & 117.27 & 66.44 \\
Apr & 8.28 & 22.60 & 70.45 & 90.61 \\
May & 12.12 & 28.31 & 43.28 & 191.34 \\
Jun & 16.92 & 34.14 & 14.61 & 463.97 \\
Jul & 19.99 & 36.02 & 8.39 & 841.90 \\
Aug & 18.48 & 34.56 & 6.49 & 758.03 \\
Sep & 13.10 & 31.73 & 14.14 & 386.19 \\
Oct & 7.16 & 25.29 & 18.35 & 172.03 \\
Nov & 2.59 & 18.94 & 30.40 & 112.77 \\
Dec & 0.23 & 12.53 & 39.36 & 90.27 \\
\hline
\end{tabular}

\subsection{Years Trend}

To get a better understanding of observed trends, the annual mean of minimum and maximum temperatures, rainfall and river discharge data were carefully analyzed through ANOVA test into five years trend for their significance at $\mathrm{p}<0.05$. In the Table $\mathbf{1}$, mean maximum, rainfall and river discharge have been observed most significant as compared to mean minimum temperature.

\subsection{Years Trend}

Hydro-meteorological characteristics have been determined through water yield/contribution per annum in 
catchment's basin and river basin analysis (Table 2).

\section{Water Yield Calculation}

Daily water yield D calculation has been carried out through an annual average value $\mathrm{X}$ from the mean annual values of different years. This average value was then multiplied with the factor 86,400 (seconds are changed into days) to get amount of water in cubic meters per day $\mathrm{Y}$. Y was then divided by the catchments area $\mathrm{Z}$ of a particular station to get daily yield in $\mathrm{m}^{3} / \mathrm{s}$ of the catchment area.

$$
\begin{gathered}
\mathrm{D}=\mathrm{Y} / \mathrm{Z} \\
\text { Where }(\mathrm{Y}=\mathrm{X} * 86,400)
\end{gathered}
$$

According to WAPDA [22] that precipitation rate in Chitral river catchment's area is comparatively low, especially the influence of the monsoon rainfall, which makes the more northern parts of the valley quite arid. Because of high altitude, precipitation mostly comes in the form of snowfall that feeds snowfields and glaciers of Hindukush Mountains.

The dataset of Chitral River shows the mean annual discharge of $277 \mathrm{~m}^{3} / \mathrm{s}$ (Table 1) with a strong monthly variance ranging from a maximum of $841.90 \mathrm{~m}^{3} / \mathrm{s}$ in July to a minimum of $66.44 \mathrm{~m}^{3} / \mathrm{s}$ in March (Table 2).

It has also been noted from the weather record of Chitral station that on average July is the hottest and driest month of the year having mean maximum temperature of $36^{\circ} \mathrm{C}$ and $8 \mathrm{~mm}$ of average rainfall whereas the mean maximum temperature of March is about $15^{\circ} \mathrm{C}$ and an average of $117 \mathrm{~mm}$ rainfall. Hence it is clear that temperature has a profound influence on the snow/glacial melt in comparison to rainfall. The discharge of Chitral River increases almost 12 times from March to July (Figure 2). The analysis also shows that maximum flow $(60 \%)$ takes place in the monsoon period i.e. Jul-Sep followed by $23 \%$ flow in pre-monsoon period. The flow duration curve (Figure 3) indicates that the discharge remains above the mean approximately $30 \%$ of the time while $60 \%$ of the time the discharge is less than the mean value. It also shows that up to $10 \%$ of the time the discharge in access of $300 \%$ to $900 \%$ of the mean flow. It means that snow/glacial cover of the area melt or retreats with respect to the climate and respond in similar way to seasonal and annual variations in discharge as suggested by Ferguson [23]. Plotting discharge values as time series (Figure 4) shows that the highest annual discharge took place in 1988 and $1992\left(320 \mathrm{~m}^{3} / \mathrm{s}\right)$ whereas the lowest discharge of $220 \mathrm{~m}^{3} / \mathrm{s}$ was recorded in 1982 . The results of the highest annual discharge are in consistent with the study of Rehman et al. [16]. The trend line indicates a clear increasing trend in the discharge rate from 1976 to 2000. The same significance trend is shown by the ANOVA result presented in Table 1.

\section{CONCLUSION}

In order to examine the influence of the rapid snow melting on Chitral river discharge at Chitral district during monsoon period July to September, the hydro-meteorological data were carefully compiled into five and twenty five year periods. The results of the study revealed that mean monthly maximum temperature has a strong influence on river discharge and impact of rainfall is relatively small because large bulk of river discharge occurs during May-September due to snow/glacial melt and receives a lot of snowfall from winter (Dec-Feb) to pre-monsoon (April-May). In the present study, 30\% of the time the discharge rate remains above the mean in the monsoon period (Jul-Sep), while $60 \%$ of the time the discharge is less than the mean in the pre-monsoon (April-May) period. It means that $10 \%$ of the time the discharge is in reach of $300 \%$ to $900 \%$ of the mean flow, indicating the signals of climate change i.e. a rise in water yield, river discharge and shortened the snow fall period due to increase in mean monthly maximum temperature. Therefore, the present study will be useful for irrigated agriculture, hydel power generation and watershed management sectors for future planning and response capabilities to disastrous effects of change in hydrological cycle on national level.

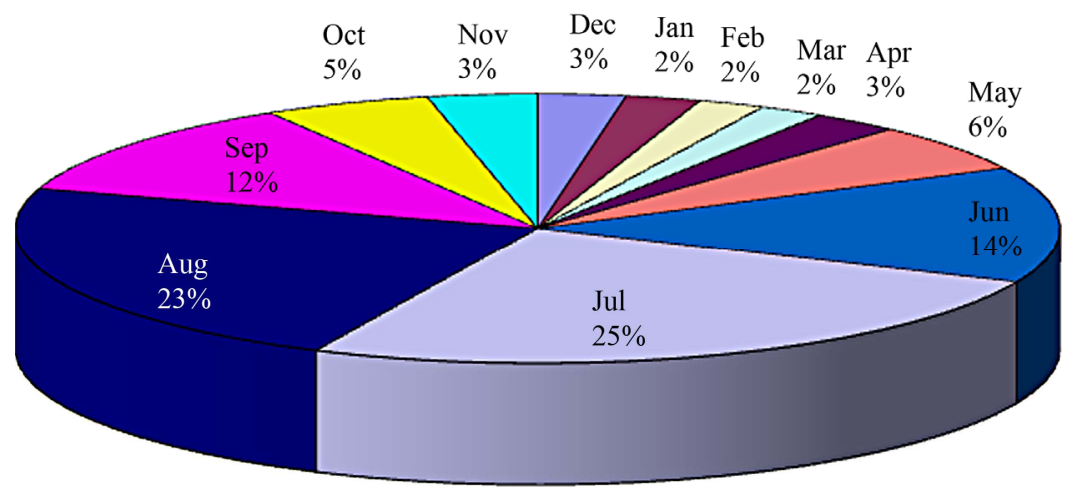

Figure 2. Monthly flow availability of Chitral River. 


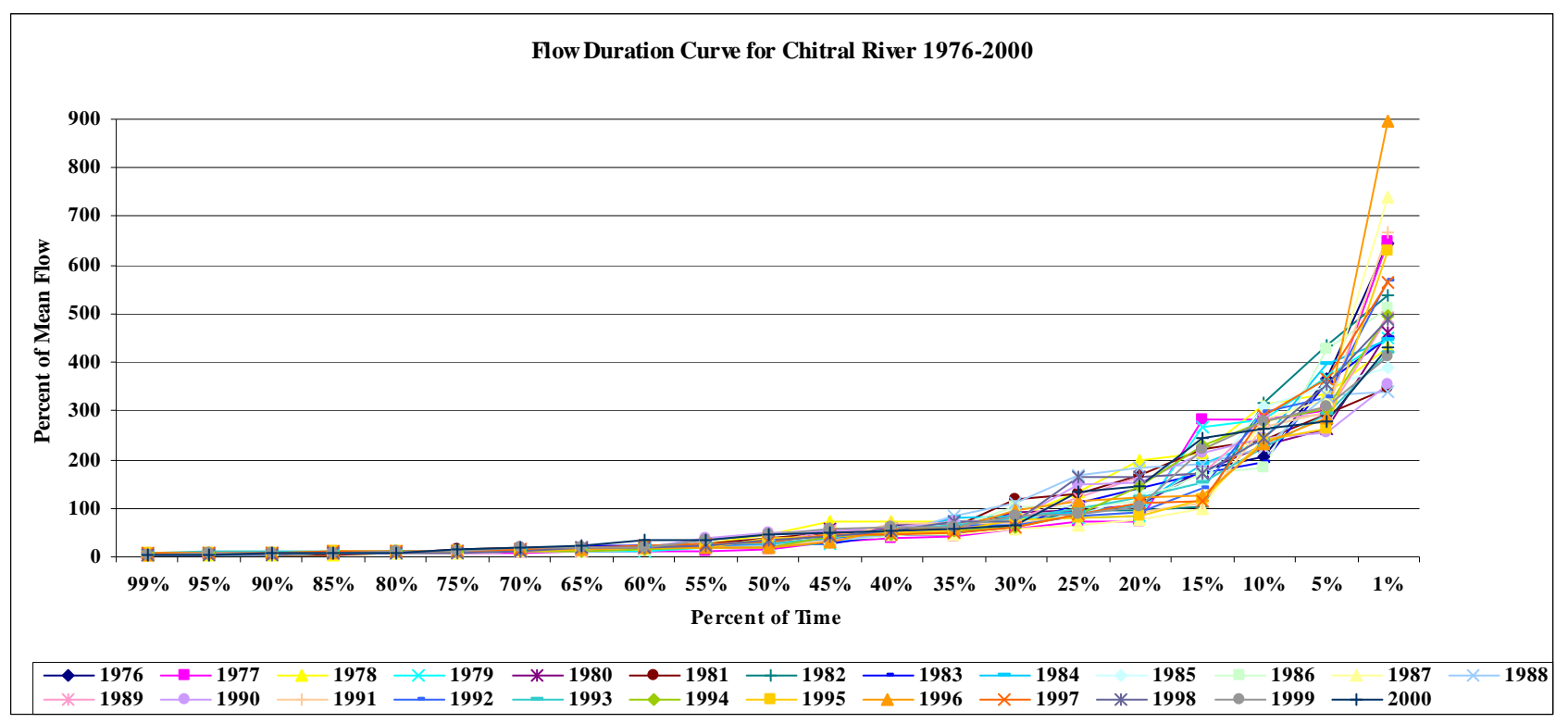

Figure 3. Flow duration curve for Chitral River from the period 1976-2000.

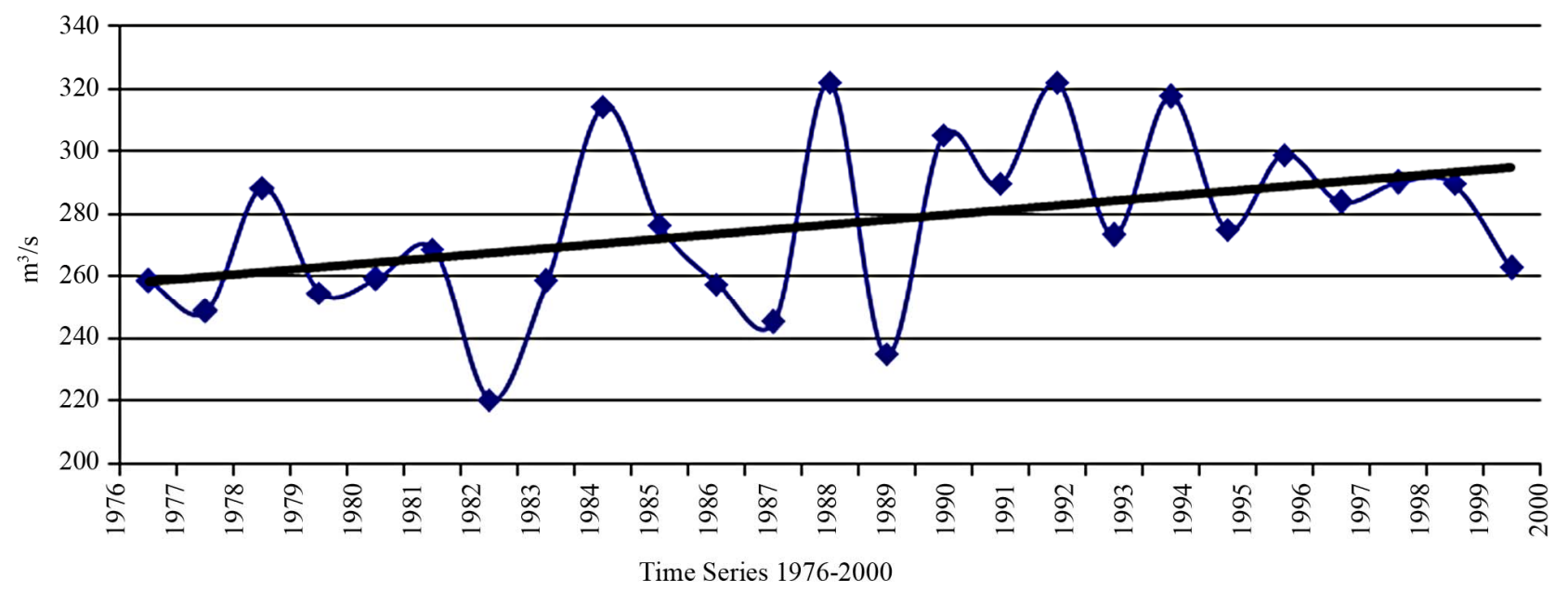

Figure 4. Hydrograph of mean annual discharge of Chitral River.

\section{ACKNOWLEDGEMENTS}

We gratefully acknowledge the PMD and WAPDA for their help in acquisition of hydro-meteorological data.

\section{REFERENCES}

[1] IPCC (2001) Climate change. The IPCC 3rd assessment report. In: Houghton, J.T., Ding, Y., Griggs, D., Noguet, M., Vander Linden, P., Dai, X., Maskell, K. and Johnson, C.A., Eds., The Scientific Basis, Cambridge University Press, Cambridge.

[2] Kundzewicz, Z.W., Mata, L.J., Arnell, N.W., Döll, P., Kabat, P., Jiménez, B., Miller, K.A., Oki, T., Sen, Z. and Shiklomanov, I.A. (2007) Freshwater resources and their mana gement. In: Parry, M., Canziani, O., Palutikof, J. and van der Linden, P., Eds., Climate Change: Impacts, Adaptation, and Vulnerability. Contribution of Working
Group II to the Fourth Assessment Report of the Intergovernmental Panel on Climate Change. Cambridge University Press, Cambridge and New York, 173-210.

[3] Allen, M.R. and Ingram, W.J. (2002) Constraints on future changes in climate and the hydrological cycle. $\mathrm{Na}$ ture, 419, 224-232. doi:10.1038/nature01092

[4] Nijssen, B., O'Donnell, G.M., Hamlet, A.F. and Lettenmaier, D.P. (2001) Hydrologic sensitivity of global rivers to climate change. Climate Change, Kluwer Academic Publishers (Netherlands), 50, 143-175.

[5] Groisman, P.Ya., Knight, R.W., Karl, T.R., Easterling, D.R., Sun, B. and Lawrimore, J.H. (2004) Contemporary changes of the hydrological cycle over the contiguous United States: Trends derived from in situ observations. Hydrometeorology, 5, 64-85.

[6] Karl, T.R. and Knight, R.W. (1998) Secular trends of precipitation amount, frequency, and intensity in the United States. Bulletin of American Meteorology Society, 
79, 231-241. doi: $10.1175 / 1520-0477(1998) 079<0231$ :STOPAF $>2.0 . C$ $\underline{\mathrm{O} ; 2}$

[7] Ayers, M.A., Wolock, D.M., McCabe, G.J., Hay, L.E. and Tasker, G.D. (1994) Sensitivity of water resources in the Delaware River Basin US Geological Survey Water-Supply. 2422 US, Geological Survey, Reston.

[8] Gleick, E.H. (1986) Methods for evaluating the regional hydrological impact of global climatic changes. Hydrology, 88, 97-116.

[9] Gleick, E.H. (1987) Regional hydrologic consequences of increases of atmospheric $\mathrm{CO}_{2}$ and other trace gases. Climatic Change, 110, 137-161. doi:10.1007/BF00140252

[10] Gleick, P.H. (1999) Studies from the water sector of the national assessment. American. Water Resources Associates, 35, 1297-130. doi:10.1111/j.1752-1688.1999.tb04216.x

[11] Lettenmaier, D.P. and Gan, T.Y. (1990) Hydrologic sensitivities of the Sacramento-San Joaquin River basin: Caldornia, to global warming. Water Resources Resident, 26, 69-86.

[12] Mather, J.R. and Feddema, J. (1986) Hydrologic conesquences of increases in trace gases and $\mathrm{CO}_{2}$ in the atmosphere, in Effects of changes in stratospheric ozone and global climate. Washington DC, US Environmental Protection Agency. Climate Change, 3, 251-271.

[13] McCabe, G.J. and Ayers, M.A. (1989) Hydrologic effects of climate change in the Delaware Kver basin. Water Resource Bulletin, 25, 1231-1242. doi:10.1111/j.1752-1688.1989.tb01335.x

[14] Nemec, J. and Schaake, J.S. (1982) Sensitivity of water resources systems to climate variation. Hydrology Science, 27, 327-343. doi:10.1080/02626668209491113
[15] Schaake, J.S. (1990) From climate to flow. In: Waggoner, P.E., Ed., Climate Change and US Water Resources, John Wiley, New York, 177-206.

[16] Rehman, S.S., Sabir, M.A. and Khan, J. (1997) Discharge characteristics and suspended load from rivers of northern Indus basin, Pakistan. Geology Bulletin University of Peshawar, 30, 325-336.

[17] Pant G.B. and Rupa Kumar, K. (1997) Climates of South Asia. Johan Wiley and Sons Ltd., Baffins Lane, Chichester, 219-224.

[18] Rasul, G., Chaudhry, Q.Z., Mahmood, A., Hyder, K.W. and Qin D.H. (2011) Glaciers and glacial lakes under changing climate in Pakistan. Pakistan Journal of Meteorology, $\mathbf{8}, 1-8$

[19] Barry, R.G. (2002) Mountain climate change and cryospheric responses: A review. In: Berger, T., Ed., Mountain of the World, Proceedings of the World Mountain Symposium (WMS 2001). Swiss Agency for Development and Cooperation, Bern.

[20] Shakir, A.S., Rehman, H. and Ehsan, S. (2010) Climate change impact on river flow in Chitral watershed. Pakistan Journal of Engineering and Applied Sciences, 7, 1223.

[21] Sabir, M.A. (1996) Qualitative and quantitative analysis of the suspended sediment from rivers of NWFP. M.Phil, Thesis, NCE in Geology, University of Peshawar, 88.

[22] WAPDA (1997b) Golgen Golhydel power project, Chitral: Feasibility study report. Hydroelectric Planning Organization, Lahore, 2.

[23] Ferguson, R.I. (1984) Sediment load of the Hunza River. In: Miller, K.J., Ed., The International Karakoram Project, Cambridge University, 2, 580-598. 